\title{
Correction: Lukša, J., et al. Fungal Microbiota of Sea Buckthorn Berries at Two Ripening Stages and Volatile Profiling of Potential Biocontrol Yeasts. Microorganisms 2020, 8, 456
}

\author{
Juliana Lukša ${ }^{1}$, Iglè Vepštaitè-Monstavičè ${ }^{1}$, Violeta Apšegaitè ${ }^{2}$, Laima Blažytè-Čereškiene் ${ }^{2}$, \\ Ramunè Stanevičienè ${ }^{1}$, Živilè Strazdaitè-Žielienè ${ }^{1}$, Bazilè Ravoitytè ${ }^{1}$,

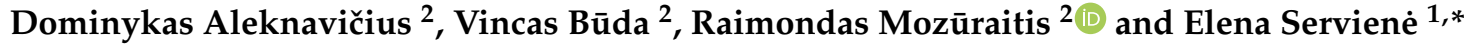 \\ 1 Laboratory of Genetics, Institute of Botany, Nature Research Centre, Akademijos str. 2, Vilnius LT-08412, \\ Lithuania; juliana.luksa@gamtc.lt (J.L.); igle.vepstaite@yahoo.com (I.V.-M.); \\ ramune.staneviciene@gamtc.lt (R.S.); zivile.strazdaite-zieliene@gamtc.lt (Ž.S.-Ž.); \\ bazile.ravoityte@gamtc.lt (B.R.) \\ 2 Laboratory of Chemical and Behavioral Ecology, Institute of Ecology, Nature Research Centre, \\ Akademijos str. 2, Vilnius LT-08412, Lithuania; violeta.apsegaite@gamtc.lt (V.A.); \\ laima.blazyte@gamtc.lt (L.B.-Č.); dominykas.aleknavicius@gamtc.lt (D.A.); vincas.buda@gamtc.lt (V.B.); \\ raimondas.mozuraitis@gamtc.lt (R.M.) \\ * Correspondence: elena.serviene@gamtc.lt; Tel.: +370-5-272-93-63
}

The authors wish to make the following corrections to this paper [1]:

The authors in the Funding section of [1] found an error. Consequently, the authors wish to correct "This research was funded by European Social Fund/European Regional Development Fund under grant agreement with the Research Council of Lithuania (LMTLT), grant number 09.3.3-LMT-K-712-01-0099." to "This project has received funding from European Social Fund (project No 09.3.3-LMT-K-712-01-0099) under grant agreement with the Research Council of Lithuania (LMTLT)."

The authors would like to apologize for any inconvenience caused to the readers by these changes.

\section{Reference}

1. Lukša, J; Vepštaitè-Monstavičè, I.; Apšegaitè, V.; Blažytė-Čereškienè, L.; Stanevičienè, R.; Strazdaitė-Žielienė, Ž; Ravoitytė, B.; Aleknavičius, D.; Būda, V.; Mozūraitis, R.; et al. Fungal Microbiota of Sea Buckthorn Berries at Two Ripening Stages and Volatile Profiling of Potential Biocontrol Yeasts. Microorganisms 2020, 8, 456. [CrossRef] [PubMed]

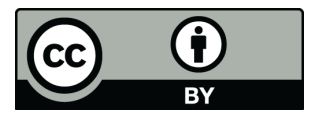

(C) 2020 by the authors. Licensee MDPI, Basel, Switzerland. This article is an open access article distributed under the terms and conditions of the Creative Commons Attribution (CC BY) license (http://creativecommons.org/licenses/by/4.0/). 